\title{
Pengaruh Penambahan Fucoidan terhadap Performa Ayam Pedaging
}

\section{Effect of Fucoidan Supplementation on Broiler Performance}

\author{
A. Nururrozi *, S. Indarjulianto, Yanuartono, S. Raharjo, dan H. Purnamaningsih \\ Departemen Ilmu Penyakit Dalam, Fakultas Kedokteran Hewan, Universitas Gadjah Mada \\ *E-mail: alfarisa.nururrozi@gmail.com
}

(Diterima: 20 Oktober 2017; Disetujui: 6 Desember 2017)

\begin{abstract}
ABSTRAK
Penelitian ini bertujuan untuk mengetahui pengaru penambahan fucoidan terhadap produktivitas pada ayam broiler. Sebanyak 100 ekor ayam broiler umur sehari (DOC) dibagi menjadi 4 kelompok dan ditempatkan pada kandang perlakuan berbeda. Kelompok P0 (kontrol) diberi pakan dan minum sesuai dengan standar umur pertumbuhan ayam. Kelompok P1, P2, dan P3 masing-masing diberi pakan dan minum yang ditambah fucoidan $2,6 \mathrm{mg} / \mathrm{mL} ; 5,2 \mathrm{ml} / \mathrm{mL}$ dan $10,4 \mathrm{ml} / \mathrm{mL}$ secara peroral. Setiap kelompok perlakuan terdiri dari empat ulangan dipelihara selama 35 hari. Rancangan penelitian yang digunakan adalah Rancangan Acak Lengkap (RAL) yang dianalisa dengan analysis of variant (Anova) dilanjutkan dengan uji duncan. Total konsumsi pakan tidak berbeda nyata $(\mathrm{P}>0,05)$ antar perlakuan $\mathrm{P} 0, \mathrm{P} 1, \mathrm{P} 2$, dan $\mathrm{P} 3$ dengan rataan berturut-turut 3462,5; 3420; 3447,5; dan 3373,7 g/ekor/35 hari. Demikian juga pertambahan bobot badan dan FCR tidak berbeda nyata $(\mathrm{P}>0.05)$ antar perlakuan. Hasil penelitian menunjukkan hasil berbeda tidak nyata $(\mathrm{P}<0,05)$ pada semua kelompok perlakuan. Berdasarkan hasil penelitian disimpulkan penggunaan fucoidan $2,6 \mathrm{mg} / \mathrm{mL}$ sampai dengan level $10,4 \mathrm{ml} / \mathrm{mL}$ belum dapat memberikan pengaruh terhadap konsumsi pakan, pertambahan bobot badan serta FCR pada ayam pedaging.
\end{abstract}

Kata kunci: broiler, fucoidan, produktivitas

\section{ABSTRACT}

The aim of this study was to determine the effect of fucoidan on productivity in broiler chickens. A total of 100 day-old broiler chicks (DOCs) were divided into 4 groups and placed in different treatment cages. The PO (control) group was fed and drunk according to the age standard of chicken growth. Groups $P 1, P 2$, and P3 were each fed and fed plus fucoidan 2,6 mg/mL; 5,2 ml/mL and 10,4 ml/mL peroralally. Each treatment group consisted of four replications maintained for 35 days. The research design used was A Completely Randomized Design (CRD) and data was analyzed with analysis of variance (Anova) followed by duncan multiple range test (DMRT). The total feed intake was not significantly different $(P<0.05)$ by treatment P0, P1, P2, and P3 which average 3462,5; 3420; 3447,5; and 3373,7 g/head/7 weeks, respectively. Similarly, body weight gain and FCR were not significantly different among treatments. Based on the results, it is concluded that the use of fucoidan $2,6 \mathrm{mg} / \mathrm{mL}$ up to $10,4 \mathrm{ml} / \mathrm{mL}$ not able to increase feed intake and body weight as well as improve FCR in broiler.

Keywords: broiler, fucoidan, productivity

\section{PENDAHULUAN}

Fucoidan merupakan senyawa polisakarida kompleks dengan komponen utama L-Fucose dan grup sulfat ester yang dapat diisolasi dari rumput laut cokelat dan invertebrata laut (seperti bulu babi dan teripang) (Chizhov et al., 1999; Li et al., 2008;
Synytsya et al., 2010). Fucoidan mempunyai berbagai macam bioaktivitas antara lain sebagai imunostimulan (Yoo et al., 2007; Ramberg et al., 2010; Teruya et al., 2010; Isnansetyo et al., 2016), antitumor/antikanker (Kawamoto et al., 2006; Kim et al., 2010; Synytsya et al., 2010), antiviral (Chotigeat et al., 2004; Elizondo-Gonzales et al., 
2012; Trejo-Avila et al., 2014), antikoagulan (Pereira et al., 1999), pemicu apoptosis, anti-proliferasi (Teruya et al., 2010), dan antioksidan (Wang et al., 2008).

Penelitian fucoidan sebagai imunostimulan pernah dilakukan pada udang sebagai antivirus pada penyakit white spot syndrome virus (Takahashi, 1998). Sebagai antivirus, fucoidan berperan dalam menghambat pembentukan inti sel virus yang terinduksi. Traifalgar et al. (2009), memberikan PPF (partial purified fucoidan) melalui pakan (oral) sebesar $60 \mathrm{mg} / \mathrm{kg}$ bobot tubuh udang per hari. Hasilnya, PPF mampu mencegah infeksi WSSV pada udang. Beberapa penggunaan fucoidan pada udang windu sebagai antibakteri yaitu tahan terhadap serangan Vibrio harveyi. Hasil penelitian Chotigeat et al. (2004), menjelaskan bahwa fucoidan mampu meningkatkan aktivitas fagositosis pada udang.

Penelitian pada bidang akuakultur telah menjelaskan bahwa fucoidan mampu meningkatkan produktivitas. Traifalgar et al. (2009) berhasil meneliti bahwa penggunaan $500-2000 \mathrm{mg} / \mathrm{kg}$ pakan udang mampu meningkatkan biomassa, rasio efisiensi protein, feed conversion ratio (FCR) yang rendah dan memiliki sintasan yang tinggi. Suplementasi fucoidan pada pakan udang selama 30 hari memberikan hasil konversi pakan yang baik dengan tingkat survival tetap tinggi (86-92\%). Suplementasi fucoidan juga tidak menyebabkan adanya perubahan komponen protein, lemak, dan komponen tubuh lain (Traifalgar et al., 2009).

Pada ilmu kesehatan manusia, fucoidan digunakan sebagai bahan dalam beberapa produk suplemen makanan dan menggantikan antasida (campuran garam aluminium, magnesium, dan simetikon) yang memiliki negatif untuk ginjal (Yoo et al., 2007; Li et al., 2008). Fucoidan yang diberikan juga bersifat sitoproteksi terhadap epitel mukosa lambung dan meningkatkan produksi growth factor (Chizhov et al., 1999; Li et al., 2008). Potensi bioaktivitas fucoidan yang beraneka macam belum pernah diteliti untuk diaplikasikan pada ayam. Tujuan penelitian ini adalah untuk mengetahui pengaruh pemberian berbagai level fucoidan terhadap pertambahan berat badan, konsumsi, dan konversi pakan pada broiler. Kegunaan penelitian ini adalah untuk memberikan informasi kepada masyarakat khususnya peternak mengenai potensi manfaat fucoidan sebagai campuran bahan pakan pada broiler.

\section{METODE}

\section{Persiapan fucoidan}

Fucoidan diekstraksi dari Sargassum $s p$. dengan metode asam, kemudian pengujian komponennya dilakukan dengan metode Kromatografi Lapis Tipis (KLT) menggunakan fase diam: silika gel, fase gerak: isopropanol, etil asetat, air dengan perbandingan berturutturut 7:2:1 dan Spektroskopi FT.

\section{Ayam}

Materi dalam penelitian ini digunakan 100 ekor ayam day old chick (DOC) broiler strain Lohmann dengan berat awal 40,33 $\pm 4,33$ gram. Ayam dibagi secara acak kedalam 4 kelompok yaitu P0, P1, P2, P3 (masing-masing 100 ekor) dan diberi nomor yang ditempelkan pada sayap. Kelompok P0 sebagai kontrol negatif tidak diberikan penambahan fucoidan, P1 P2 dan P3 masing-masing diberi pakan dan minum yang ditambah fucoidan $2,6 \mathrm{mg} /$ $\mathrm{mL}$. $5,2 \mathrm{ml} / \mathrm{L}$ dan $10,4 \mathrm{ml} / \mathrm{L}$ secara peroral. Pemberian fucoidan dilakukan dicampur melalui air minum dan diberikan mulai dari hari pertama pemeliharaan selama 3 hari dalam seminggu. Pengamatan produktivitas (konsumsi pakan, pertambahan berat badan, dan FCR) dilakukan setiap hari.

\section{Pemberian pakan}

Pemeliharaan dilakukan selama 35 hari dengan pemberian pakan sesuai dengan standar strain ayam (Lohmann Manual Management). Pada periode starter pakan yang diberikan berbentuk tepung/mash dengan komposisi air $12 \%$, protein kasar $21 \%$, lemak kasar $4 \%$, serat kasar 4,5\%, kalsium $0,9-1,1 \%$, fosfor $0,7-0,9 \%$, dan periode finisher menggunakan 
pakan berbentuk crumble dengan komposisi air $13 \%$, protein kasar $19-21 \%$, lemak $5 \%$, serat kasar $5 \%$, kalsium $0,9 \%$, fosfor $0,6 \%$. Air minum diberikan secara ad libitum selama pemeliharaan.

Frekuensi pemberian pakan berbedabeda disesuaikan dengan umur ayam (Lohmann Manual Management). Ayam umur satu sampai 15 hari frekuensi pemberian pakan empat kali dalam sehari yaitu pada pukul 06.00, 12.00, 18.00, dan 24.00. Ayam umur 15 sampai 21 hari diberikan pakan tiga kali dalam sehari yaitu pada pukul 06.00, 14.00 , dan 21.00 sedangkan untuk ayam yang berumur 21 sampai 35 hari hanya diberikan pakan dua kali dalam sehari yaitu pukul 08.00 dan pukul 18.00 .

\section{Pengamatan performa ayam}

Parameter performa ayam yang diamati meliputi perhitungan konsumsi pakan, pertambahan berat badan, dan konversi pakan. Konsumsi pakan merupakan pakan jumlah yang dihitung setiap hari dengan cara menghitung pakan yang diberikan dikurangi sisa pakan (g/ekor/hari). Pertambahan bobot badan (g/ekor) ayam broiler ditimbang setiap minggu untuk mendapatkan data bobot badan, data total PBB didapat dari penimbangan bobot badan akhir dikurangi bobot badan awal. Konversi pakan dihitung dari jumlah pakan yang dikonsumsi dibagi dengan PBB.

\section{HASIL DAN PEMBAHASAN}

Data hasil penelitian pengaruh penambahan fucoidan dalam air minum terhadap performa ayam pedaging yang meliputi rata-rata konsumsi pakan, pertambahan bobot badan, dan konversi pakan dapat dilihat pada Tabel 1.

\section{Konsumsi pakan}

Berdasarkan penelitian yang telah dilakukan, penambahan fucoidan dengan berbagai level berpengaruh terhadap total konsumsi pakan, tetapi tidak memiliki pengaruh pada pertambahan berat badan dan konversi pakan. Total konsumsi pakan berbeda nyata $(\mathrm{P}<0,05)$ pada $\mathrm{P} 0, \mathrm{P} 1, \mathrm{P} 2$, dan P3 berturut-turut 3462,$5 ; 3420 ; 3447,5$; dan 3373,7 g/ekor/35 hari. Standar normal konsumsi pakan ayam lohmann yang dipelihara hingga hari 35 adalah 3360-3550 g (Aviagen, 2007). Kelompok yang memiliki total konsumsi pakan terendah adalah P3 dan $\mathrm{P} 2$, sedangkan kelompok kontrol memiliki total konsumsi pakan tertinggi. Menurut penelitian oleh Wahju (2004) konsumsi pakan pada ayam broiler yang dipelihara menggunakan kandang open house system adalah 3350-3500 tergantung dari kualitas pakan, strain ayam, dan metode pemeliharaan.

Traifalgar et al. (2009) menyatakan bahwa penambahan fucoidan dalam pakan hingga $400 \mathrm{mg} / \mathrm{kg}$ dapat memperbaiki konsumsi pakan. Fucoidan merupakan senyawa polisakarida yang mengandung L-fukosa dan ester sulphate Fucoidan juga merupakan senyawa yang berfungsi sebagai protektor lambung (Chizhov et al., 1999; Li et al., 2008). Komponen polisakarida kompleks dalam fucoidan yang diduga menyebabkan ayam merasa cepat kenyang setelah minum sehingga menyebabkan penurunan konsumsi pakan. Pemberian fucoidan terlebih dahulu sebelum pemberian pakan yang menyebabkan isi perut ayam sudah terisi dengan fucoidan dan membuat ayam tidak mau mengambil pakan. Baiao dan Lara (2005); Deachamag et al. (2006) menjelaskan bahwa faktor utama penambahan polisakarida adala tingkat kecernaan yang sangat tergantung dari banyak faktor diantaranya komposisi pakan, panjang rantai karbon, dan banyaknya ikatan rangkap.

\section{Pertambahan berat badan}

Rata-rata pertambahan berat badan tertinggi, berturut-turut terjadi pada kelompok P2 (2093,7 g), P1 (1996,2 g), P0 (1950,2 g), dan P3 (1910,6 g). Standar normal pertambahan berat badan ayam lohmann yang dipelihara hingga hari 35 adalah 2124-2220 g (Aviagen, 2007). Hasil analisa statistik menunjukkan penambahan fucoidan tidak menyebabkan perbedaan nyata $(\mathrm{P}>0,05)$ pada pertambahan berat badan antar kelompok (Tabel 1). Pada minggu pertama 
Vol. 20 (1): 15-20

Tabel.1 Rata-rata konsumsi pakan, pertambahan bobot badan, dan konversi pakan selama penelitian (35 hari).

\begin{tabular}{lcccc}
\hline \multirow{2}{*}{ Variabel } & \multicolumn{4}{c}{ Perlakuan } \\
\cline { 2 - 5 } & P0 & P1 & P2 & P3 \\
\hline Konsumsi pakan & $3462,5 \pm 47,2^{\mathrm{a}}$ & $3420,0 \pm 59,1^{\mathrm{a}}$ & $3447,5 \pm 42,9^{\mathrm{a}}$ & $3373,75 \pm 78,2^{\mathrm{b}}$ \\
PBB (g/ekor) & $1950,2 \pm 42,7$ & $1996,2 \pm 42,9$ & $2093,7 \pm 75,8$ & $1910,6 \pm 80,2$ \\
Konversi pakan & $1,78 \pm 0,12$ & $1,72 \pm 0,09$ & $1,65 \pm 0,10$ & $1,77 \pm 0,07$ \\
(g/ekor) & &
\end{tabular}

Keterangan: ${ }^{\text {a,b }}$ Superskrip yang berbeda pada baris yang sama menunjukkan perbedaan yang nyata $(\mathrm{P}<0,05)$

hingga minggu ketiga terdapat pertambahan berat badan yang lebih baik pada kelompok yang diberi perlakuan fucoidan, akan tetapi menjelang panen pertambahan berat badan melambat dan bobot panen menjadi tidak berbeda nyata. Kelompok P2 memiliki ratarata pertumbuhan berat badan yang paling baik dibandingkan kelompok lain. Temuan ini konsisten dengan penelitian lain pada bidang akuatik yang menjelaskan potensi growth promotor fucoidan yang telah dibuktikan pada P. japonicus dan Litopenaeus vannamei (Traifalgar et al., 2009).

Berdasarkan hasil pertambahan berat badan harian dapat kita simpulkan bahwa pertambahan berat badan terbaik adalah kelompok P2 dan P1. Dari keseluruhan hasil pertambahan berat badan sekilas tidak begitu nampak adanya perbedaan signifikan ataupun berat badan yang kurang dari kontrol. Pertambahan berat badan pada kelompok perlakuan lainnya menunjukkan penurunan berat badan setiap minggunya meskipun beratnya tidak kurang dari berat badan kontrol. Berat badan pada kelompok P1 mengalami kenaikan pada minggu pertama hingga ketiga, kemudian minggu keempat dan kelima mengalami penurunan secara simultan. Pada kelompok P3 berat badan ayam mengalami penurunan disetiap minggunya meskipun tidak kurang dari berat badan kontrol, sedangkan pada kelompok P2 berat badan mengalami kenaikan di minggu pertama dan minggu ketiga, pada minggu kedua mengalami penurunan berat badan yang tidak begitu signifikan.

Menurut Anitha et al., (2006) umur ayam berpengaruh pada pertambahan bobot yang dimana pada periode starter atau awal umur dari ayam meningkat secara cepat, kemudian mulai melambat dan mengalami rerata penambahan berat badan menjelang panen. Penambahan fucoidan sebagai suplemen penambah pada pakan dan mengalami penurunan berat badan pada umur dewasa.

\section{Konversi pakan}

Nilai FCR dari kelompok P0, P1, P2, dan P3 berturut-turut 1,$78 ; 1,72 ; 1,65$; dan 1,77. Hasil penelitian menunjukkan hasil berbeda tidak nyata $(\mathrm{P}<0,05)$ pada semua kelompok perlakuan. Standar FCR ayam lohmann yang dikatakan baik pada pemeliharaan hingga hari 35 adalah 1,5-1,65 (Aviagen, 2007). Kelompok P2 memiliki nilai konversi pakan yang terbaik disebabkan karena total konsumsinya yang lebih sedikit rerata berat panen yang paling baik. Dari hasil penelitian disimpulkan penggunaan fucoidan $2,6 \mathrm{mg} / \mathrm{mL}$ dan $5,2 \mathrm{ml} / \mathrm{mL}$ mampu menurunkan konsumsi pakan dan memperbaiki FCR pada ayam pedaging.

Traifalgar et al. (2009) menjelaskan bahwa suplementasi menggunakan polisakarida dari Macrocytis pyrifera (Deachamag et al., 2006) mampu meningkatkan digestibilitas nutrisi, menghasilkan efisiensi daya cerna protein dan meningkatkan rata-rata pertumbuhan pada $L$. vannamei muda. Peningkatan pertumbuhan pada suplementasi fucoidan dapat dihubungkan sebagai dampak peningkatan efisiensi dan asimilasi yang diakibatkan dari aktivasi fasgositosis pada hepatopankreas yang memproduksi enzim proteolitik (Traifalgar et al., 2009). 


\section{KESIMPULAN}

Penambahan fucoidan dengan berbagai level berpengaruh terhadap total konsumsi pakan, tetapi tidak memiliki pengaruh pada pertambahan berat badan dan konversi pakan.

\section{UCAPAN TERIMA KASIH}

Proyek penelitian ini sepenuhnya terselenggara atas Hibah Penelitian Pengembangan Departemen Fakultas Kedokteran Hewan UGM dengan judul "Pengaruh Fucoidan Terhadap Produktivitas Ayam Pedaging", sesuai Surat Penugasan Pelaksanaan Pekerjaan Nomor 1176 /J01.1.22/ HK4/2017 dari FKH UGM, Yogyakarta, Indonesia. Terimakasih juga kepada PIAT UGM untuk dukungan sarana dan prasarana penelitian.

\section{DAFTAR PUSTAKA}

Anitha, B., M. Moorthy, and K. Viswanathan. 2006. Production performance of broiler fed with crude rice bran oil. Int. J. Poult. Sci. 5 (11): 1046-1052.

Aviagen. 2007. Lohman Meat Broiler Stock Performance Objectives. Aviagen Corp. Alabama, USA

Baiao, N.C, and L.J.C. Lara. 2005. Oil and fat in broiler. Brazilian J. Poult. Sci. 7(3): 129-141

Chizhov, A.O., A. Dell, and H.R. Morris, 1999. A study of fucoidan from the brown seaweed Chorda Filum. Carbohydr. Res. 320: 108-119.

Chotigeat, W., S. Tongsupa, K. Supamataya, and A. Phongdara. 2004. Effect of Fucoidan on Disease Resistance of Black Tiger Shrimp. Aquaculture 233: 23-30.

Deachamag, P, U. Intaraphad, A Phongdara, and W. Chotigeat. 2006. Expression of a Phagocytosis Activating Protein (PAP) gene in immunized black tiger shrimp. Aquaculture, 255, 165-172.
Elizondo-Gonzalez, R., L. E. Cruz-Suarez, D. Ricque-Marie, E. Mendoza-Gamboa, C. Rodriguez-Padilla, and L. M. TrejoAvila. 2012. In vitro characterization of the antiviral activity of fucoidan from Cladosiphon okamuranus against Newcastle Disease Virus. Virology Journal, 9:307 < http://www.virologyj. com/content/9/1/307>

Isnansetyo, A., A. Fikriyah, N. Kasanah, and Murwantoko. 2016. Nonspecific immune potentiating activity of fucoidan from a tropical brown algae (Phaeophyceae), Sargassum cristaefolium in tilapia (Oreochromis niloticus). Aquacult Int. DOI 10.1007/ s10499-015-9938-z.

Kawamoto H, Y. Miki, T, Kimura, K. Tanaka, T. Nakagawa, M. Kawamukai, and H. Matsuda. 2006. Effects of Fucoidan from Mozuku on Human Stomach Cell Lines.

Food Science and Technology Research. 12: 218-222.

Kim, E.J., S.Y. Park, J.Y. Lee, and J.H.Y. Park. 2010. Fucoidan present in brown algae induces apoptosis of human colon cancer cells. BMC Gastroenterology. 10:96. $\quad<\mathrm{http}: / / \mathrm{ww} w . b i o m e d c e n t r a l$. com/1471-230X/10/96> (diakses 9 Oktober 2017)

Li B., F. Lu, X. Wei, and R. Zhao. 2008. Fucoidan: structure and bioactivity. Molecules. 13: 1671-1695.

Pereira, M.S., B. Molloy, and P.A.S. Mourão, 1999. Structure and Anticoagulant Activity of Sulfated Fucans. J. Biol. Chem. 274: 7656-7667.

Ramberg J.E., E.D. Nelson, and R.A. Sinnott. 2010. Immunomodulatory dietary polysaccharides: a systematic review of the literature. Nutrition Journal. 9:54. <http://www.nutritionj.com/ content/9/1/54> (diakses 9 Oktober 2017)

Synytsya, A., W.J. Kim, S.M. Kim, P. Radek, S. Alla, K. František, C. Jana, and Y.I. 
Park. 2010. Structure and Anti tumour Activity of Fucoidan Isolated from Sporophyll of Korean Brown Seaweed Undaria pinnatifida. J. Carbohydrate Polymers. 81: 41-48.

Teruya T., S. Takeda, Y. Tamaki, and M. Tako. 2010. Fucoidan isolated from Laminaria angustata var longissima induced macrophage activation. Bioscience Biotechnology Biochemistry. 74: 19601962.

Thitamadee, S., K. Sritunyalucksana, A. Prachumwat, T.W. Flegel, J. Srisala, O. Itsathitphaisarn, and P. Jaroenlak. 2016. Review of current disease threats for cultivated penaeid shrimp in Asia. Aquaculture 452 (2016) 69-87.

Traifalgar, R. F., Serrano, A.E., Corre, V., Kira, H., Tung, H.T, and Koshio, S. 2009. Evaluation of Dietary Fucoidan Supplementation Effects on Growth Performance and Vibriosis Resistance of Penaeus monodon Postlarvae.
Aquaculture Sci. 57 (2): 167-174

Trejo-Avila, L.M., M. E. Morales-Martınez, D. Ricque-Marie, L. E. Cruz-Suarez, P. Zapata-Benavides, K. MoranSantibanez, and C. Rodrı'guez-Padilla. 2014. In vitro anti-canine distemper virus activity of fucoidan extracted from the brown alga Cladosiphon okamuranus. VirusDis. 25 (4): 474-480

Wahju, J. 2004. Ilmu Nutrisi Unggas. Cetakan ke-5. Gadjah Mada University Press. Yogyakarta

Wang, L., B. Zhi, W. Wu, and X. Zhang. 2008. Requirement for shrimp caspase in apoptosis against virus infection. Dev. Comp. Immunol. 32, 706-715.

Yoo, C.Y., W.J. Kim, S.Y. Kim, S.M. Kim, M.K. Chung, J.W. Park, H.H. Suh, K.B. Lee and W.I. Park. 2007. Immunomodulating activity of a fucoidan isolated from korean Undaria pinnatifida Sporophyll. Algae. 22: 333338. 